
2
E M
I N G
R

謙虚な大学作文教育論一日本人の論文執筆力を磨こう一-1

\title{
初めての英語論文執筆へのアドバイス 学術的自我を確立する10の質問集
}

\section{舘野佐保}

青山学院大学アカデミックライティングセンター

毎年, 秋冬の今時期といえば, 翌春の卒業へ向けて学 部生や大学院生が論文執筆に取り組む頃である、研究室 の教員は論文指導に多くの時間を割くこととなる．初め て英語論文投稿に挑戦する学生に対して, 教員が論文指 導をする機会もあるのではないだろうか. 昨今の論文捏 造報道を受けて, 研究不正防止の倫理教育の必要性が叫 ばれるなか, 果たして「研究モラルの欠如」のみを現状 課題として捉えていれば良いのだろうか. 良識ある研究 活動の実践として, 学術的文章作成の実践的なトレーニ ングは欠かせない.どんなに AI（人工知能）のような テクノロジーがさらなる発展をしたとしても, 学術的文 章作成の難しさと身につけておくべき基本は普遍的なも のである. 本稿では, 限られた時間で誰でもコッコッ進 められる英語論文執筆教育の方法を模索し提案してみ る.

\section{言葉を失った若者たち}

度重なる自然災害や緊迫する国際情勢などから，「言 葉を失ってしまう」心境が続いてしまいがちな時代にあ る. 他方で, 普段の執筆環境やスタイルは, 時代ととも に変遷を遂げてきた．文章力は社会的な暮らしや就労に おけるコミュニケーション能力の一つとして基本である.

論文発表が研究評価基準の一つとして推奨されている が, 日本の研究コミュニティ全体の出版状況について見 渡すと, 国際競争力の低迷が指摘されて久しい。学術情
報データベースのトムソン・ロイター「Web of Sci-

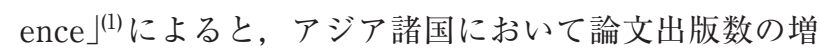
加は目覚ましく, 2009年から 2016 年の 8 年間でマレー シア $14.9 \%$, 中国 $14.0 \%$, シンガポール $7.5 \%$ であるが, 一方で日本は $0.5 \%$ であり, 世界平均 $4.1 \%$ と比べても研 究力としての論文出版数が伸び悩み, 飽和状態である.

深刻な現状を危惧した日本政府は，大学改革およびイ ノベーション推進の一環として2018年 6 月に閣議決定さ れた「統合イノベーション戦略」(2)において次のように 述べている.

《大学改革等によるイノベーション・エコシステムの創 出》

(平成 30 年 6 月 12 日閣議決定「統合イノベーション戦略 第三章知の創出」より)

1 研究生産性の向上

目標・2023年までに研究大学の教員一人当たりの 論文数・総論文数を増やしつつ, 総論文数に占める Top $10 \%$ 補正論文数の割合を $12 \%$ 以上

施策 ・競争的研究費の一体的な見直し（科研費等の 若手への重点化, 挑戦的な研究の促進等)

2 ボーダレスな挑戦 (国際化, 大型産学連携)

目標・2023年度までにTop $10 \%$ 補正論文数におけ る国際共著論文数の増加率を欧米程度

施策・2019年度に外国企業との連携に係るガイド ラインの策定 


\section{連載開始にあたつて：理系作文の重要性を改めて考える}

学術論文を執筆していると，結論を導くために必要な実験 が足りないと気づくことはないでしょうか。私にはよくあり ます。これは書く作業を通じて論点が整理されるという一例 ですが，本来ならば書き始める前に，どのように論理を展開 し，そのためにはどのような実験が必要か十分に検討される べきです．この論理を組み立てる作業は，授業で課されるレ ポート作成の場合と基本的には同じです，教員から出された 課題に対し, 主張の根拠となる「素材」を調查・収集し, そ れらを組み合わせることによって結論を導いていく．理系 コースの卒業論文や修士論文では，自ら実験を行うことに よって「素材」を収集するわけですが, 論理構築の基本は 授業レポートと変わりはなく, その延長線上にジャーナルで の学術論文の出版があります。このような論理的記述は，学 術論文の執筆だけでなく, さまざまな提案書や企画書の作 成のためにも重要な素養の一つでもあります。

私がポスドクとしてアメリカの某大学に滞在していたと き, Ph.D.コースの学生が prelims（学位論文研究を始める にあたり行われる予備試験）で課される研究提案書（proposal）の作成を通して, 論理的記述を徹底的に鍛えられ る様を目の当たりにしました。翻って，日本ではどうで しょうか. 大抵の場合は，「まずは実験して，学位論文は
期日までに書いてね.」というスタンスで, 教員も学生も 「実験」そのものを重視し，社会で本当に必要な論理的記 述・思考のトレーニングは個人の努力に委ねられているよ うに思われます。

上述の伝統的なライティングの重要性に加え, 近年で は, 研究機関や企業に打ける研究内容 (業務内容) やその 成果をわかりやすく発信する必要性が高まってきていま す. 大学のウェブページからは最新の研究成果へアクセス できるようになって㧍り，その内容が（多くの場合，プレ スリリースという形で）説明されています。しかし，必ず しもすべての記事が一般の人に理解しやすく書かれている とは限りません。一方で, 取材を通して研究活動をわかり やすい言葉で紹介する独自のコンテンッを配信している大 学もあります。

本連載では, ライティングの理論と実践を体系的に学 び，ライターや編集者として経験を積んだ舘野佐保先生 (農学系大学出身) に, 日本各地の大学研究機関で行って きた作文講義やセミナーを事例として，日本の理系作文教 育の現状と今後の課題をさまざまな角度から論じていただ きます。

(東北大学大学院農学研究科 新谷尚弘)
科学政策の一つとして，具体的に「いまから 5 年間で 論文出版数や国際共著論文数を増やす」と目標を掲げて いる. しかし，施策についてみてみると，研究費見直し や国際連携ガイドライン見直しのみとなって㧍り，目標 を実現するためのロードマップが明快ではない，研究現 場において教員が論文指導をできる時間が減少している にもかかわらず，現場での奮闘にのみ期待が寄せられて いるのが現状である，本稿では，まず言語の違いにかか わらず近年顕在化してきた「作文教育にまつわる課題」 について述へ，その後筆者が提供した「英語論文執筆を 目標としたトレーニングプログラム」について記述す る.

《現代の作文にまつわる課題》

a）即席完成形ネット上における「見かけ上完成品」 の横行

b）SNS全盛自身の科学的考察より他者への見栄えを 優先

c）執筆テクノロジー パソコンのコピー\&ペース 卜機能等の使用に対する倫理観

\section{a）即席完成形}

情報テクノロジーの目覚ましい進歩により, コミュニ
ケーションを助けるアプリやッールが日々開発されてい る．使い勝手さえ理解していれば，テキストを入力する だけで即時にウエブサイトやブログを更新でき，誰でも 自由に発信できるようになった。便利さの恩恵に預かっ ている他方で，デメリットもある．文章推敲の機会がな いまま誰でも言葉を出版できるようになった。学術出版 およびジャーナリズムの役割はかつて「情報の門番」や 「社会のウオッチドッグ」であったが, 現在のネット情 報の状況は門番不在な情報洪水となってしまっている.

他者の文章をインターネットで閲覧するとき，ウエブで 更新されていれば「間違いのない完成形」だとみなして しまうことがあり問題である，本来であれば，文章とは一 言一言を積み重ね，長い時間をかけて作成されるもので あった，論文については今もそうであるが，論文執筆に 取り掛かるときにも，普段のスタイルの延長線上に捉えて しまうことがある。論文はワンクリックで即席にできるも のではなく, 論文執筆における時間的感覚が求められる.

\section{b）SNS全盛}

ソーシャルネットワーキングサービス，すなわち SNS であるッイッターやフェイスブック，ラインなどは, 機 能そのものはシンプルであるが担う役割の変遷はめざま 


\section{$\bowtie$ ラ $\bowtie \bowtie$}

時計がチクタク動くように, 自分の心を動かす何か

よく大学や研究所の先生から, 学生がどうしたら もっと論文を書けるようになりますか? とお尋ねい ただくすると決まって「まずは、将来の夢を言葉に してみる練習から始めては」と㨫えするようにして いる，母国語である日本語か，もしくはたどたどしい 英語であったとしても, 事始めとしてふさわしい. 400 字詰め原稿用紙1枚, もしくは A4 白紙 1 枚を学生 一人一人へと配布し，20分程度の時間があれば十分 だろう。

将来の夢を書いてもらうなど, まるで小学生の作文 のようである。だが，馬鹿には出来ない。試しに高 校生や大学生, 大学院生に書いてもらうと, たった 1 枚の作文執筆から多くの発見がある。素朴なテーマ で書いてもらったとしても，学生は上手く書けない ことに気づくのだ。まずは学生に「あれ?」と拍子抜 けしてもらうこと自体が, 作文教育のスタート地点 となる.

言葉が出てこない。 アイデアが漠然としている. 頭のなかにすでに書きたいことはあり，スラスラと書 けるつもりだったにもかかわらず，実際にはそうな らない.キーワードは挙げられたとしても文章とし て説明ができない...など，様子に個人差はあったと しても，いかに書けないかを口にする。もしくは，た とえ将来の夢が書けたとしても, 学生の半数以上が 「普段どおりの暮らしを続けることが夢です」と無難 な回答をする。インターネットで誰もがリアルタイ ムに発信でき，自在に会話をしている現在.いつも スマートフォンなどから言葉を送り合っているにも かかわらず, 研究や教育の現場において学生は考元 を思うように言葉にできている訳ではない。

これはひとまず無理もないことだと，筆者は考え ている. 現代の高校生や大学生, 大学院生の世代は, 数々の自然災害を幼少期や 10 代といった感受性の鋭 い時期に経験している。政治や経済など国際情勢の 緊迫した時期も経てきた。子供時代に見聞きしてき た大人の言葉は，夢について語っていたというょり もむしろ諦観の念を吐露していたことが少なくはな
かったのではないだろうか.

いっぽうでこのような時代に生きる若者達であっ ても, 研究者を志すか, もしくは社会へ出て就職す るという人生の岐路にいる. 研究の業績発表や就職 の応募のために，言葉を磨き，文章を作り，「自身が 何者であり, どんな知識経験があり, これからどん な研究や仕事をしていくことに興味をもっているの か」について伝わるようにできなければならない。そ れも，相手に納得してもらう必要がある。そここで，あ る質問の回答を書いてみてもらいたい.

“What makes you tick?”（どんなことに知的関心 がありますか?）

留学先の大学で, 作文講義の先生が言っていた言 葉だ、質問での “tick”とは, 英語で時計がカチコチ と時を刻む音（tick-tack）のことを示している。まず は, 何かを読んでいて心に響いた点, 興味深い点に ついて，自分の好きな物や趣味についてでも良い。 まずは「流暢に書けるようにすること」を目的とし， 臆することなく言葉を書き出してもらう，日記を書 いて定期的に提出してもらうのも効果的である.

これは「書き言葉の声」を獲得していく作業につ ながっていく．書くことによってより深く考え理解 できるようになる，慣れてきたら，いよいよ関心の ある研究テーマや将来の夢をもう一度書いてもらう。 そうすれば，以前よりもずっと形になることが多い． その際，「教える側」が定期的に読んで前向きな感想 を送り続けることで, 学生の「基本的な書く力」が 身についていく. 文法力や語彙表現力は, 教える側 に直してもらうよりも, 繰り返し書いてみることに よって自然と体得できる部分がある。そうしてよう やく，考えを述べられるようになってくる.

書くことは日常化しているが, SNSでテキストを送 り合うことと, 論文のような学術的文章の作成は, 違っている.まずは「いかに書けないか」に驚いても らい，学術的文章を「書くこと」自体について興味を もってもらう. 書き言葉の声を獲得し, 知的関心や将 来の夢を言葉にできるようになれば, 次は研究活動や 卒業後の進路へ向けた行動にうつすことができる。こ こまで出来るようになるのは, 簡単なようで意外に時 間と努力を要する. 学生の言葉や書く力を引き出しな がら教えられるのが大切だと考えている.
しい. 東日本大震災時にSNSで最新の情報を得られる メリットが理解され，ライフライン関連や交通機関など にまつわる公的機関もッイッターで積極的に情報発信す るようになった。デマやフェイクニュース問題は引き続 きやっかいではあるが, 伝統的な新聞雑誌のマスメディ アとソーシャルメディアとの連動は今後も続くだろう.

論文では科学的な仮説の検証を目的として記述する
が，SNSでは相手の反応を最優先にしてしまいがちで ある。取り扱う内容, 文体, 語彙などについて, SNS と論文では執筆時のスタイルが違っている。その際, 問 題となるのは，原稿を自身で評価する能力ではないだろ うか．書いたものを見直し，本当に伝えたい事柄が述べ られているか, 論理展開などの推敲するプロセス, すな わち「書いたものを鏡として思考する時間」が執筆の時 
間だったはずだ。時間をかけて仕上げなければ，文章を 送った先の他者に評価を委ねるのみになってしまう。自 身の考えを書き表して評価するというプロセスを，作文 教育で体得してもらうべきである.

\section{c）執筆テクノロジー}

今ではスマートフォンのみならず最新のITが数多く開 発され続け, 今後は AIやビッグデータを介した対人コ ミュニケーションのツールが文章執筆のスタイルを変化 させていくだろう．だからこそ，執筆テクノロジー使用 時の倫理観については, 教育現場で議論を続けていく必 要がある.たとえば, パソコンのシンプルな「コピー\& ペースト」について考えて見ると，わかりやすい. よく 「コピペ問題」という表現が使われるが，コピペ自体に罪 はない.コピペは機能であり, どのように使いこなすの かを, 教育する必要がある。自身の原稿で, 他者から文 章を扯借する場合は, 引用元を明示することになってい るが，明示できていない場合はルール違反となる.

コピペと同様, 画像処理機能についても線引きが必要 となる．また，スマートフォンを用いて論文の下書きを する学生も増えてきている。これからも, 論文執筆時に 便利なテクノロジーが開発されていくことが予測され, 10年後にはどのようなスタイルが論文執筆の主流と なっているかは, 今は想像がつかない. だが, 機能の使 いこなし方㧍よび不正となる使用法について, 教育現場 で注意喚起をしていく必要がある.

これらの現代社会における作文の課題は, 教育現場で 話題にし，学生と議論の機会を設けることにより，大幅 な改善の余地があると筆者は考えている.

言葉を失っている状況——文章を書けず，研究モラル が低下していると思われている状況の背景には，以上の ような現代の作文にまるわる諸問題がある。では，現状 の問題点を踏まえつつもどのように理系向けに作文教育 を進めると良いのか，話を進めたい．

\section{学術的自我を確立する 10 の質問}

大学教育現場からは, 従来の授業や研究室での教育の 姿を尊重しつつも，「何かをプラスして教えることで, 学生には書くことについての活気を取り戻してもらいた い」との要望が作文教育の専門家へ寄せられる。もしく は，少し前までは「アカデミックリテラシー」すなわち 教養の一部として誰でも当たり前に備わっていた授業・ 研究活動時の書く力を現在の学生にも身につけてもらい たいとの声も少なくない.

\section{表 1 - 論文が受理されないときの代表的な理由}

・別論文との差異がそれほどない

・投稿先ジャーナルの投稿規定に沿っていない

・実験方法およびデータ分析の検討が不十分

・結論部の妥当性が足りない

・論文に明記すべき項目が書かれていないまたは項目の不備（タイト

ル, 著者名, 著者所属先, キーワード, 本文, 文献リスト, 図表)

・本文の言語・文章表現が査読できる質になっていない

・図が不明瞭

・著者向けガイドラインのフォームに同意をしていなかった

・文献リストが古すぎるもしくは不備

・他のジャーナルで査読中の内容だった

・研究不正（捏造改ざん剽窃）を含む論文である

・言語, 構成, 図表がよく練られていない

・退屈な内容である

ジャーナル編集長のP. Throwerによるコメント Wiley Research Academy 提供

要望に応えるためには, 現在, 理系作文教育として 「ギャップ間の橋渡し」となるようなプログラムが望ま しいのではないだろうか，英語論文の出版において，準 備する学生は英語表現を最も気にしやすいが，「論文が 受理されないときの代表的な理由」(3)の（表1）をご覧い ただければわかるように，実際はそれ以外の理由により 論文が受理されていない場合も多いようである.

だからと言って，英語論文投稿に消極的になっていて は，もったいない. せっかく優れた実験デー夕を発表す る機会をもつのならば，国際的に自身の研究を知っても らうために英語論文出版に挑戦してみるべきだ。そのた め, 学生が日常で綴るスマートフォンでのテキストと, 論 文執筆のような学術的文章の執筆スタイルのギャップ, 日本語と英語の言語についてのギャップ，さらには一般 論を気軽に語る場合と科学について専門的に議論する場 合のギャップなど，ギャップを橋渡ししてあげられるよう な機会を与えて繰り返し訓練してみることで, 日常生活 に打ける文章を通じたコミュニケーションから日本語で の学術的文章執筆, 英語での科学論文の出版にまで「段 階を追って」執筆が上達するよう見届けることができる。

今回は，ある国立大学医学部の若手支援セミナーおよ び現職での大学院生向けの作文講座でも実施してきた, 英語論文執筆を目標としたトレーニング法を紹介する. 10 個用意した質問を投げかけて，学生に書いて回答し てもらう。言葉一つひとつを積み上げ，わからない書き 方の詳細があれば些細なことでも教員に書き方を尋ねて もらい, 一緒に情報構築を試みる。 


\section{Decide how to take notes メモを取る方法は自分} で決められていますか ?

海外の英語を母国語としない留学生向けに課される英 文力向上のトレーニングを海外大学院留学時に筆者は 1 年ほど受講したが, 英語が母国語でない学生が英文力を 身につけるためには，すべての論文作業工程について 「ゆっくり時間をかけて進めること」に尽きる。これに より, 英語ネイティヴではないというハンデイは乗り越 えられる. しかし, 理系学生の場合は実験に一日の多く の時間を費やしているため，集中的な論文執筆の時間を 作ることが難しい.

そこで，論文執筆の下書きやアイデアをまとめる「メ モ」が重要になってくる。ノートやメモ帳でも良いし， パソコンの下書き機能もしくはスマートフォンを使用し ても良い. 自身のメモ書きのスタイルを学生に決めても らうことを勧める。論文の書き始めから完成までに，一 貫して同じメモの取り方をすることで，論文の構想を 練ったり細部の検討をしたりするときに効率が良い。こ の際，実験ノートとは別に一連のメモを作成するほうが 整理整頓しやすい.

論文の構成は,「タイトル, 著者名, 所属先, 概要, 導入, 実験方法, 結果・考察, 結論, 文献リス卜」が一 般的であり，それぞれの項目ごとに求められる学術的文 章作成のポイントがある。一度に全貌が姿を表すように 書き上げるつもりで取り組むのではなく，むしろ論文の 項目ごとに分解して捉えるほうが良いだろう。項目ごと に作成し，パズルを組み立てるつもりで完成を目指すほ うが，着実だ。

たとえば，導入部分では「文献を引用する文章」を作 成できる必要があるし，実験方法では料理のレシピのよ うに「時系列に説明する」能力が求められる。結果部分 では先行研究と自身の実験デー夕，もしくは仮説と実験 デー夕を「比較して記述する」能力が求められる。一本 の論文も，まずは一語や一文，一つの段落から始まる. メモ書きに少しずつ書きためることから始めてもらう.

\section{Make a map after brainstorming 書くときの設 計図はメモから書き起こせますか?}

和文でも英文でも，作文トレーニングというと語彙や 文法の正確さのみと考えてしまいがちであるが，それ以 外にも教えるべきことは多い。学術的文章を作成する際 は，特に「書くための準備」が大切になってくる.メモ 書きはそれぞれの個性にあって雑多なものでも構わない が，下書きやメモ書きから一度，設計図を作成してもら うと次へのステップヘとつながりやすい.
何を伝えて何を伝えないのか論点を絞り，どのような 順序で伝えるのかも検討する．研究者の中には，こう いった論旨，論理展開のことを論文執筆に扔ける「ス トーリー展開」や「ストーリー性」と呼ぶ場合もあり, でき栄えを左右する。

学生の書いた原稿について日々読んでいると, 全体の 構成や骨組从がわかって書けている場合とそうでない場 合に雲泥の差がある．書くべきことが多すぎて困ってい るような学生には,「これだけは伝えなければならない」 という最小限の情報や論点を選んでもらう。始めは肩时 張らず，何度でも変更可能であると伝えてまずは「暫定 的な設計図」を考案してもらうのが良いだろう．設計図 を作成してもらうことで思考が論理的になり，検討が足 りない部分を見いだせる。

\section{Try paragraph writing 一つの段落でそれぞれど んな主張をしますか?}

パラグラフライティングは, 作文の基本として多くの授 業や書籍で取り上げられている. 英語についてのみなら ず，日本語でも「一つの段落で一つの主張」を述べていく と, 学術的文章の場合はシンプルに論理構築しやすい.

では，パラグラフライティングを復習してみよう。段 落の初めに「トピックセンテンス」として主張もしくは 段落ごとのメインとなる文章があり，それに「サポート センテンス」として具体的な事例やデー夕による説明が 続く. 段落最後には, まとめの「クロージングセンテン ス」があって次の段落へとつなげる.

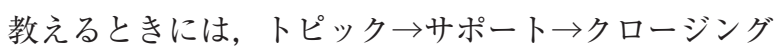
の流れを確認してあげれば, 一つの段落としてまとまり が出てくるだろう. 何が主張で, 何が主張の根拠となる 事例やデータで, 結局そこから何が言えるのか. バラバ ラになっているキーワードやデー夕を，段落ごとに小分 けにしていく．段落ごとにしっくりくる文章となれば, 段落同士が理路整然として積み上がっていくだろう。

馴染みがなければ, パラグラフライティングの構造を 意識して，段落一つだけをまずは作成する練習が始めや すい. 自身の研究について, 日常生活についてでも良い ので，パラグラフライティングの記述法を身につけるこ とで, 科学的・学術的な段落を書けるようになる第一歩 となるだろう。

\section{Show your three reasons $3 つ$ の論点や理由で説 明できますか?}

書くべきことの設計図を作成してもらい，パラグラフ ライティングも練習した次には，まずは 3 行でアイデア 
を説明してもらうと良いだろう。書こうとしている文章 全体の論点や，主張の根拠を説明できるようになる。も ち万ん4つでも5つでも構わないが, 複数個に焦点を定 めて論理展開する練習をする。もし考えがまとまらな い，何も浮かばない，という学生がいれば，まずは 10 個でも 20 個でもキーワードを挙げてもらい，たくさん

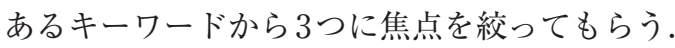

授業の課題レポートや学術論文では,「現在行った実 験や考察をすべて書き表すことが目的ではない」という ことを学生になるべく強調する．そう伝えることによっ て，メモに数多くの下書きをしたとしても書かなくても 良い部分があり, 最も伝えなければならない結果や論点 から結論を導けば良いのだ，ということに気づいてもら う.

\section{Tell it chronologically 時系列に並べて説明でき ますか?}

アカデミックな文章の論理展開には形式が数とおりあ る.一つは, 論点 $3 つ$ 程度の列挙, 二つ目は, 時系列に 並べる書き方である.プロセスに従って書く方法とも言 える、たとえば, 「小学校から中学校, 高校, 大学で何 のクラブ活動をしていたか」，もしくは「料理のレシ ピ」,「電化製品の取扱説明書」も時系列に並べて説明し てある。

学術論文では「実験手法」の部分は時系列に沿った説 明で書かれており，順を追って説明することをまずは箇 条書きから始めてもらうのも良いかもしれない，学生に 実際に時系列に並べて書いてもらうと，どのぐらいの情 報を時系列の文章に含めるのか，苦労するようである. 実験レポートや学術論文では，読み手が害際に再現して 実験が可能な手法を書くべきであるが，実際には原稿の 文字数も加味して全体のバランスで情報量の過不足を検 討するだろう。

\section{Explain it by comparison 比較して論じられます か?}

アカデミックな論理展開の形式について，3つ目は比 較である。「論点 $3 つ 」, 「$ 時系列」,「比較」, これらの形 式で解説ができれば，大体の議論はできるだろう。ジェ ネラルな話題について書くのであれば，「都会と田舎」 や「自動車と自転車」などを比較して共通点と相違点を 述べることで練習となる.

論文執筆の練習であれば,「先行研究と実際の実験 データの結果との比較」もしくは「仮説と実際の実験 データとの比較」について共通点と相違点を記述してみ
る，比較して論述する練習をして見ると，学生は書くの にかなり時間を費やす，文章を書くときに，単なる印象 論ではなく具体的な項目について検証して順を追って説 明するトレーニングとして非常にためになるだろう。比 較して考察することとなり, 勉強の足りない点や, 追加 実験が必要な部分などがわかってくる場合もある.

\section{Introduce objectively what you have read 先行 研究を一つ選び紹介できますか？}

研究活動において, 原点となるような先行研究が誰に でもあるだろう，先行研究となる文献を一つ選び紹介す る文章を書く練習は，学術的文章作成の最も基本的な卜 レーニングの一つと言える. 何が優れているのか，その 文献以前と以後で何が違ったのか. 客観的に述べてみ る.

さらに作文教育として密度の濃いトレーニングを実施 するのであれば, 紹介の仕方をアカデミックライティン グの基本に則っていくつかのパターンで紹介できるよう に書く練習を勧める。

(1) Quote 文献から文章をそのまま抜き取り引用. 引用 元を明示しながらカギカッコ「」を用いて紹介する.

(2) Paraphrase 文献一部分について言い換えた引用. 引用元を明示しながら自分の言葉で紹介する。

(3) Summarize 文献全体の要約. 引用元を明示しなが ら概要を自分の言葉で紹介する.

これら 3 とおりの方法で文献を紹介できると, 論文執 筆の際に議論の幅が広がりやすくなる．引用文の書き方 について詳しく学びたい方には, 海外の大学院にて留学 生向けの授業で使用されているテキスト” Keys for Writers”(4)を推薦する.

\section{Make a list of research articles 文献のリストを 作成できますか？}

レポートや論文を執筆する基本として, 原稿で引用す る文献のリストを作成できるようにする，英文の場合は 科学系の分野ではAPAスタイルトという表記方法を使 用することが多い．昨今ではRefWorksなど読んだ文献 を引用スタイルごとにリストを作れるツールがあるの で，実際に論文を作成する際には使用すると便利であ る.

作文のトレーニングとしては，文献リストを一度じっ くりと時間をかけて作成してもらうことを勧める．思っ たよりも時間のかかる作業であるうえに，どの文献を論 文で使用するか取捨選択する機会ともなる．同時に, PDF化した論文の整理整頓をするタイミングにもなる. 
9. Contextualize three researches you have influenced by the most 先行研究を複数選び文脈を作れま すか?

論文のイントロダクションでは, 先行研究を紹介する 必要がある。「どのような専門分野のどのような流れで 今回の研究を実施するのか」について, 説得力ある論法 で記述する，その際，それぞれの先行研究をどのように つなげ，自身の新しい文脈を作っていくのかが腕の見せ 所であり，論文の見せ場の一つとなる．先行研究の説明 の仕方や, 先行研究同士をつなげて研究背景を説明する ことで, 自身の研究の重要性やまだわかっていないこと がらが十分に伝わらなければならない.

学生のトレーニングでは，まず，どの先行研究を選ぶ のかを検討して，それぞれの先行研究をどの順番でどの ように説明するのか書いてもらう. 文系学部の学生より も, 理系学部の学生のほうが先行研究の引用表記につい て教育を受ける機会は少ないのではないだろうか. 理系 学部の学生に対しては，まずは実験デー夕ありきである のは言うまでもない.しかし，日本の理系作文教育では イントロダクションの書き方をもう少しじっくり行うこ とで, 自身の専門分野を説明する力や，研究全体を見渡 して論文執筆も実験も積極的に取り組めるようにする力 が身につくのではないだろうか.

10. Take a stance on literature 動詞表現によって スタンスを明示し先行研究を批評できますか?

論文を執筆するときに，論文著者は先行研究に対して 考えを述べていかなければならない。その際に，スタン スを明示することが求められる。 ある科学的仮説につい て，もしくは主張について，論文著者として賛成なのか 反対なのか，さらに明らかにすべきなのはどのようなこ となのか, 説明する.

学生に対する指導では, 批評のための英文執筆におい て「動詞表現」に着目して取り組んでもらうと取り組み やすいようである. 先行研究が, 論文著者の研究にとっ てどのような意義をもつのか, 証明する (prove), 分 類する (categorize)，分析する (analyze) など，動詞 表現によって限定して読み手に伝えられるからである. 論文のイントロダクションなどで先行研究の説明につい て「何をどのように書けば良いのか，言葉が出てこな い」と学生が困っていたら,「まずは主語に先行研究の 著者やキーワードを選び，次に動詞を選んでください」 とアドバイスして取り組んでもらうのである.

先行研究の批評にとどまらず, 論文の結果考察や結論 の部分においても, 動詞表現に着目して指導することは
効率的である.

筆者は，以上のような質問 10 項目についての英文執 筆トレーニングを 2 日程度の時間をかけて集中的にセミ ナーや講義で主に大学院生やポスドク向けに取り組んで もらっている。半年程度の時間をかけて，一週間に一つ の質問に回答してもらうような指導方法もあるだろう. 回答を書いてもらいながら，いつのまにか書くことに慣 れてくる，漠然としていたアイデアが，筋道を立てて形 を帯びてくることに，きっと驚くだろう．

ここまで述べてきた内容の元になっているのは，海外 留学で実際に受けた体系的な作文の授業や海外の学術出 版社にて見聞きしてきたことがらである。日本では，理 系作文の授業自体が少ない．授業があったとしても講義 形式や著名科学者の論文執筆体験談に終始している場合 がほとんどである。そのようなケースの場合，実際の執 筆は聴講者が自習する時間に委ねられる。しかし，本来 実践的な執筆トレーニングを目的とするならば，スポー ツや音楽での基礎練習のような「実技」としてもっと学 術的文章作成の指導をできるはずである。今回紹介した 質問 10 項目は, 英語論文を書き始める学生に対して, 論理的に考えるヒントを与え，具体的な言葉を引き出す ための一助となるだろう。これまで受け身な姿勢で単に 与えられた研究テーマに取り組んできたような学生も, 本気で英語論文執筆に向き合うことによって科学的思考 の時間をもつことができ, 結果として, 論文発表や学術 的自我を確立できる好機になるだろう。

「すべては書いてみなければ始まらない, ということ がわかった」、筆者のセミナーを受講した医学部学生が 述べた感想である。「書けない」と思ったときに，どう するか. 強引なコピペ混じりの原稿で提出するのではな く, 学生の躓きに教員が応え, 段階を追って「書けるよ うになるプロセス」を経験してもらう。それが自信とな り, 次につながる。世間では感情を倳るような諭法や, 論理の飛躍, もしくは誇張とも言える印象づけの論法が 横行している. だからこそ, 教育現場や研究現場では, かえって「謙虚に」自身の実験デー夕や論文執筆時の言 語と向き合う姿勢を教えるのが良いのではないか，一見 簡単に思えるような事柄に, 回数を重ねて何度も確認し ていく．こういったことが社会に出てからも説得論法習 得以前に大切で, 地道に謙虚で緻密な論文執筆を教えて もらうことが，筆者にとってはプロの書き手を目指すう えで有用だったと考えている. 
文献

1) Thomson Reuters: Web of Science, http://www. webofknowledge.com, 2018.

2) 内閣府：統合イノベーション戦略, http://www8.cao. go.jp/cstp/tougosenryaku/index.html, 2018.

3) Wiley, Wiley Researcher Academy, http://news.wiley. com/wileyresearcheracademy, 2018.

4) A. Raimes \& S. K. Miller-Cochran: Keys for Writers 7th Edition, Cengage Learning, 2016.

プロフィール

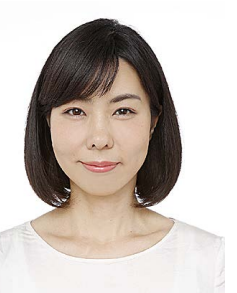

舘野 佐保 (Saho TATENO)

$<$ 略歴 $>$ 東北大学大学院農学研究科修士課

程修了/米国イースタンミシガン大学大学

院英米文学科作文コミュニケーション学科

修士課程修了／米国学術出版社John Wi-

ley \& Sonsにて生命科学編集者および出 版マネージャーを務め, フリーランスとし て学術雑誌Natureでの英文記事執筆や雑 誌連載，览童書の企画制作などに携わった 後, 現職 <研究テーマと抱負 $>$ 作文教育, 作文研究 (Rhetoric \& Composition Studies), 理系作文倫理, 生命科学 $<$ 趣味 $>$ フ ルート, 美術館や博物館巡り<所属先ホー ムページ>https://www.agulin.aoyama. ac.jp/ja/writingcenter
新谷 尚弘 (Takahiro SHINTANI)

<略歴>1991年東北大学農学部農芸化学 科卒業/1997年同大学大学院農学研究科 博士課程修了 / 1996年日本学術振興会特 別研究員 (DC2, 東北大学) / 1998年日本 学術振興会特別研究員 (PD, 基礎生物学 研究所) $/ 2001$ 年ミシガン大学博士研究 員 $/ 2004$ 年東北大学大学院農学研究科助 教授 $/ 2007$ 年同准教授, 現在に至る<研 究テーマと抱負>酵母・カビにおける環境 ストレスに応答したタンパク質分解，錮菌 を用いた異種タンパク質生産＜趣味＞仕事 から帰って猫に遊んでもらうこと

Copyright （C２019 公益社団法人日本農芸化学会 DOI: 10.1271/kagakutoseibutsu.57.173 